\title{
Nuevos sentidos en torno a la gestión patrimonial
}

Valeria Belén Martín Silva | Universidad de Huelva, Centro de Estudios e Investigaciones en Antropología y Arqueología (San Juan, Argentina)

URL de la contribución <www.iaph.es/revistaph/index.php/revistaph/article/view/3801>

La activación del patrimonio implica un proceso de reconocimiento y valorización que, lejos de ser un proceso automático o inocente, genera narrativas que al centrarse en determinados aspectos del patrimonio moldean las formas en que las personas se relacionan con su pasado, evidenciando un proceso de construcción social (TORRES; ROMERO, 2005). De este modo, la ciudadanía se encuentra afectada directamente por la gestión del patrimonio y por tanto debe tener su correcta cabida en las decisiones y actuaciones que se toman en relación al patrimonio.

Como plantea Paño Yañes (2012), que ciertos ámbitos sean gestionados por profesionales no quiere decir que ellos deban ser los únicos que puedan tomar decisiones al respecto. Muchas veces los procesos de democratización cultural se basan en discursos patrimoniales ya definidos, cayendo en un diálogo unidireccional en donde los ciudadanos terminan por ser meros espectadores de su patrimonio; son vistos como clientes o consumidores patrimoniales pero no participan de la construcción colectiva de las narrativas patrimoniales (ARJONES FERNÁNDEZ, 2015).

En este sentido, los procesos de patrimonialización y sociabilización del patrimonio implican una complejidad estructural y conceptual que deja al descubierto la necesidad de construir un diálogo bidireccional entre instituciones/gestores culturales/investigadores(as) y comunidad (LIMA TÓRREZ, 2003), generando espacios de construcción colectiva y dialógica del conocimiento. Frente a esto, creemos que debe propiciarse una reapropiación por parte de las comunidades de su patrimonio, a través de una gestión cultural basada en procesos participativos y de vida asociativa que permitan que la población sea participe en la producción y disfrute de los bienes patrimoniales.
Si bien puede parecer utópica esta visión de la gestión patrimonial, existen en España y, en particular, en Andalucía, varios ejemplos de buenas prácticas patrimoniales propiciadas tanto desde las administraciones, universidades y demás sectores oficiales, como desde colectivos ciudadanos que buscan repensar la relación entre patrimonio, identidad y comunidad.

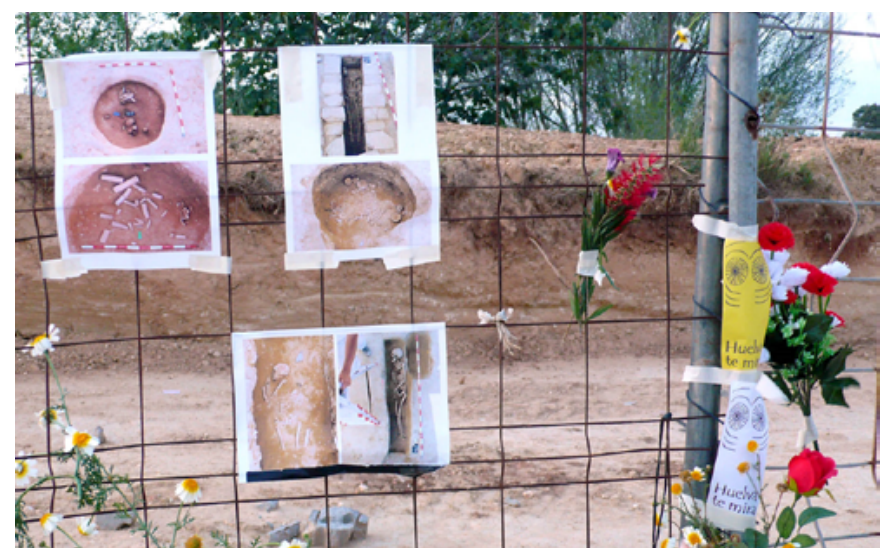

Perfomance en el yacimiento La Orden-Seminario | foto Valeria Belén Martín Silva

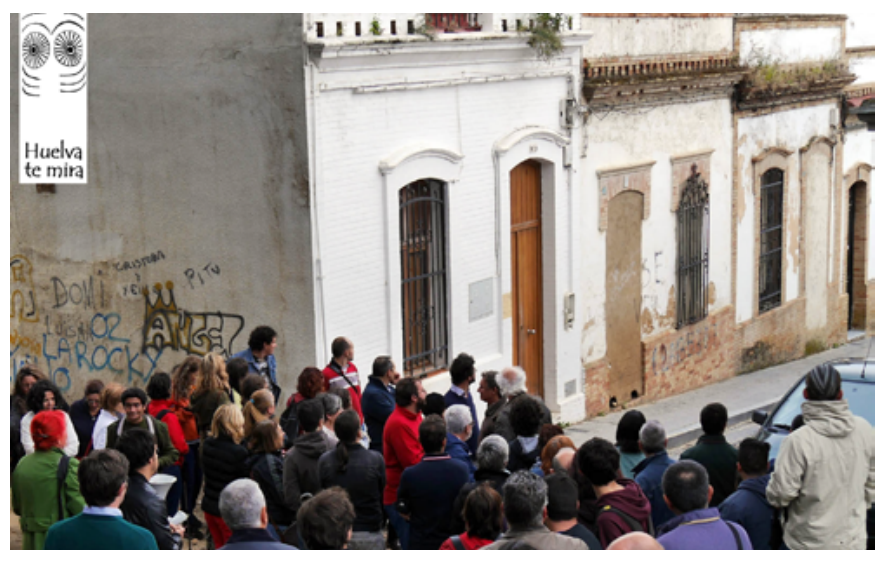

Sendero reivindicativo por el cabezo de la Joya | foto Valeria Belén Martín Silva 
Claro ejemplo de esto, es la plataforma ciudadana Huelva te mira - de la cual formo parte- que si bien surgió como reacción a un caso concreto de expolio arqueológico en la ciudad de Huelva a principios del 2016, supo canalizar la necesidad de la población onubense de volver a relacionarse y redescubrir su paisaje cultural. A través de metodologías participativas, como diagnósticos de la situación patrimonial en Huelva y performances en el sitio arqueológico expoliado, hemos desarrollado diferentes actividades que han permitido que la ciudadanía participe y sea protagonista de su patrimonio. Otro punto sobre lo que se ha trabajado constantemente es enfocarnos sobre ese desconocimiento que la población local tenía y tiene sobre su patrimonio arqueológico, histórico, geológico, paleontológico; a pesar de la riqueza patrimonial que posee la ciudad de Huelva hay una preconcepción errónea del paisaje cultural onubense. A través de la realización de senderos por los cabezos de la ciudad, paseos por la ría, actividades con asociaciones vecinales, se fueron planteando acciones para generar espacios de reflexión y debate en torno a lo patrimonial que han permitido dotar a los ciudadanos de herramientas para ser sujetos críticos de su realidad patrimonial.

Creemos que no es un camino fácil pero la clave es hacer partícipe a la ciudadanía en la toma de las decisiones y crear un esquema de gestión que permita dinamizar la vida social y cultural de una comunidad, teniendo presente las particularidades de cada lugar y adaptando los modelos de gestión a las necesidades de sus habitantes. Aspecto esencial para que los ciudadanos dejen ser meros espectadores y se comience a pensar en un gestión "desde" y no exclusivamente "para" los ciudadanos.
- LIMA TÓRREZ, M. del P. (2003) Participación comunitaria Desarrollo Sostenible y Arqueología: El caso de Quila Quila (Chuquisaca, Bolivia). Chungara, Revista de Antropología Chilena, vol. 35, n. ${ }^{\circ}$ 2, pp. 361-365

- PAÑO YAÑES, P. (2012) Gestión del patrimonio cultural y participación ciudadana. Presupuestos participativos como ejemplo de decisión y gestión compartida del patrimonio cultural entre instituciones públicas y ciudadanía. Treballs d'Arqueologia, n. ${ }^{\circ} 18$, pp. 99-123

- TORRES E.; J. ROMERO (2005) Gestores culturales. Entre la cultura y el patrimonio. Bulletin de l'Institut Français d'Études Andines, n. ${ }^{\circ} 34$ (3), pp. 277-288

\section{BIBLIOGRAFÍA}

- ARJONES FERNÁNDEZ, A. (2015) Apuntes para un Manual de buenas prácticas para la participación ciudadana en la gestión del patrimonio cultural en Andalucía. Periférica Internacional. Revista para el análisis de la cultura y el territorio, n. ${ }^{\circ} 16$, pp. $45-50$ 